\title{
Multivariate analysis of mineral constituents of edible Parasol Mushroom (Macrolepiota procera) and soils beneath fruiting bodies collected from Northern Poland
}

\author{
Magdalena Gucia • Grażyna Jarzyńska • \\ Elżbieta Rafal • Magdalena Roszak • Anna K. Kojta • \\ Irena Osiej • Jerzy Falandysz
}

Received: 19 April 2011 / Accepted: 19 July 2011 /Published online: 2 August 2011

(C) The Author(s) 2011. This article is published with open access at Springerlink.com

\begin{abstract}
Caps and stipes of 141 fruiting bodies of Parasol Mushroom (Macrolepiota procera) and surface layer of soils collected from 11 spatially distant and background (pristine) areas in Northern Poland were analyzed for $\mathrm{Ag}$, $\mathrm{Al}, \mathrm{Ba}, \mathrm{Ca}, \mathrm{Cd}, \mathrm{Co}, \mathrm{Cr}, \mathrm{Cu}, \mathrm{Fe}, \mathrm{Hg}, \mathrm{K}, \mathrm{Mg}, \mathrm{Mn}, \mathrm{Na}, \mathrm{Ni}, \mathrm{P}$, $\mathrm{Pb}, \mathrm{Rb}, \mathrm{Sr}$, and $\mathrm{Zn}$ by inductively coupled plasma optical emission spectroscopy and cold vapor atomic absorption spectroscopy. In terms of bioconcentration and bioexclusion concept, $\mathrm{K}, \mathrm{Ag}, \mathrm{Cu}, \mathrm{Rb}$, and $\mathrm{P}$ were highly bioconcentrated in caps, and their bioconcentration factor values varied for the 11 sites between 120 and $500-67-420,70-220,10$ 170 , and 45-100, respectively. Cd, $\mathrm{Zn}, \mathrm{Mg}$, and $\mathrm{Na}$ showed bioconcentration factors (BCFs) between 3.3 and 36, 3.7$15,0.92-6.3$, and 1.4-44 while Al, Ba, $\mathrm{Ca}, \mathrm{Co}, \mathrm{Cr}, \mathrm{Mn}, \mathrm{Ni}$, $\mathrm{Pb}$, and $\mathrm{Sr}$ were excluded $(\mathrm{BCF}<1)$. The Parasol Mushroom is a species harvested in the wild, and its caps are of unique taste and can contain a spectrum of essential and hazardous mineral compounds accumulated at elevated concentrations, even if collected at the background (pristine) areas. These elevated mineral concentrations of the caps are due to the efficient bioconcentration potential of
\end{abstract}

Responsible editor: Elena Maestri

Electronic supplementary material The online version of this article (doi:10.1007/s11356-011-0574-5) contains supplementary material, which is available to authorized users.

M. Gucia • G. Jarzyńska $(\bowtie) \cdot$ E. Rafał • M. Roszak •

A. K. Kojta $\cdot$ I. Osiej · J. Falandysz

Research Group of Environmental Chemistry,

Ecotoxicology and Food Toxicology,

Institute of Environmental Sciences and Public Health,

University of Gdańsk,

18 Sobieskiego Str,

80-952 Gdańsk, Poland

e-mail: grazyna.jarzynska@gmail.com the species $(\mathrm{K}, \mathrm{Ag}, \mathrm{Cu}, \mathrm{Rb}, \mathrm{P}, \mathrm{Cd}, \mathrm{Zn}, \mathrm{Mg}$, and $\mathrm{Na})$ and abundance in the soil substrates $(\mathrm{Al}, \mathrm{Ca}, \mathrm{Fe}, \mathrm{Mn})$. The estimated intake rates of $\mathrm{Cd}, \mathrm{Hg}$, and $\mathrm{Pb}$ contained in Parasol Mushroom's caps show a cause for concern associated with these metals resulting from the consumption of between 300- and 500-g caps daily, on a frequent basis in the mushrooming season.

Keywords Food $\cdot$ Fungi $\cdot$ Heavy metals $\cdot$ Mineral composition $\cdot$ Nutrition $\cdot$ Mushrooms $\cdot$ Wild food

\section{Introduction}

Fungi represent a highly biodiverse group of biota with an estimated number of above 300,000 species worldwide that are able to dissolve take-up and introduce metals from organic and soil mineral substrates into the biosphere (Gadd 2007; Gumińska and Wojewoda 1988). Among fungi, about 10,000 species are fleshy mushrooms (macrofungi, macromycetes, higher fungi). Around 2,000 mushrooms growing in the wild from more than 30 genera are considered edible (Chang 1990). Edible wild mushrooms can contain, in the flesh, a spectrum of mineral macro- and micronutrients, nonessential trace elements, and problematic heavy metals. Mycorrhizal and saprobe mushrooms take part in a biogeochemical turnover of all mineral constituents contained in soil compartments or other substrates in which mycelium develops. Despite the fact that they hold a key role, the biological mechanisms and environmental factors that drive and influence the metal bioconcentrations and content of fruiting bodies are poorly known. Mercury can be an example of a metal that is much more enriched in fruiting bodies of mushrooms than in plants or animals 
(Chudzyński et al. 2009, 2011; Falandysz 2002; Falandysz and Brzostowski 2007; Falandysz et al. 2002a, b, c, d, 2003a, b, c, 2004, 2007a; Jarzyńska and Falandysz 2011a, b; Melgar et al. 2009; Stijve and Besson 1976; Stijve and Roschnik 1974). Some mushrooms were found recently as efficient accumulators and even hyperaccumulators of noble metals such as gold and silver and examples are the Amanitas mushrooms (Amanita submembranacea and Amanita strobiliformis) or the Agaricus mushrooms (Borovička et al. 2005, 2007, 2009, 2010; Falandysz et al. 1994a, b; Falandysz and Danisiewicz 1995). Certain mushrooms are specifically rich in arsenic, iron, selenium, or vanadium (Stijve et al. 1990, 1998; Falandysz 2008; Falandysz et al. 2001, 2007b, 2008a, b). Edible wild-grown mushrooms, as mentioned, can accumulate both essential and toxic metals and metalloids in the flesh, but knowledge on the toxicological risk and nutritional benefits of such substances in edible mushrooms and mushroom meals is still low (Alonso et al. 2003; Baptista et al. 2009; Carvalho et al. 2005; Cenci et al. 2010; Cocchi et al. 2006; Falandysz et al. 2011; Frankowska et al. 2010; García et al. 2009; Malinowska et al. 2004; Melgar et al. 1998; Vetter and Siller 1997; Zhang et al. 2010).

Documentation on trace element composition of wild food is important, both to know the amount and intake rates as well as their time trends due to anthropogenic emission and environmental pollution. This study is part of an ongoing wild mushrooms survey aimed to investigate the mineral content and composition and bioconcentration of mineral constituents of Parasol Mushroom (Macrolepiota procera) growing in Northern Poland. Assessed also was the contamination status of this mushroom as well as its mineral intake rates, nutritional significance, and risk to consumers.

M. procera (Scop. Fr.) Singer (1946), formerly called Lepiota procera and known under the common name Parasol Mushroom, has an edible and delicious cap. This mushroom is a soil-inhabiting saprophytic species growing alone or scattered in woods or at the edges of woods, or in pastures and is common in Poland. Parasol Mushrooms can be purchased commercially in Poland, but because of the relatively fragile structure of its cap, it is rarely offered at the rural markets, while easily available from roadside sellers in the countryside. In this article, the concentrations of 19 metals and phosphorous in soils and edible caps and inedible stipes (which have hard and fibrous texture) of Parasol Mushrooms from 11 distant sites in Northern Poland, are reported. Soil phosphorous and trace element composition were investigated to determine possible differences between the various locations as well as bioconcentration factors (BCFs) in the Parasol Mushroom.

\section{Materials and methods}

A set of 141 well-grown and roughly similar in size (cap diameter) and shape (parasol-shaped) specimens of the Parasol Mushroom (M. procera) Bull. Fr. and corresponding surface layer $(0-10 \mathrm{~cm})$ of humifying and mineral soil beneath fruiting bodies were collected from 11 geographically distant sites in Poland (Fig. 1). The mushrooms were air-dried for several days after clean up with a plastic knife from any visible plant vegetation and soil substrate debris. Further, each specimen was separated into two parts- the cap with pileipellis (skin) and stipe - and dried at $65^{\circ} \mathrm{C}$ to constant weight. The dried mushrooms were pulverized in an agate mortar and were kept in brand new sealed polyethylene bags in dry condition.

The pulverized subsamples $(400 \mathrm{mg})$ of caps and stipes were weighted into pressure-resistant and analytical quality prodigestive vessels made of polytetrafluoroethylene, predigested for $24 \mathrm{~h}$ with concentrated nitric acid (65\%; Suprapure $^{\circledR}$, Merck; $7 \mathrm{~mL}$ ) at room temperature and further digested under pressure in an automatic microwave digestion system type (MARS 5 of CEM Corp., Matthews, NC, USA). The digest was diluted to $25 \mathrm{~mL}$ using deionized water and was subjected to instrumental analysis (Brzostowski et al. 2009).

Soil samples were air-dried in room temperature in clean condition for several weeks and were sieved through a pore size of $2 \mathrm{~mm}$ and further dried in an electric oven $40^{\circ} \mathrm{C}$ to constant weight. Next, the soil subsamples $(\sim 5 \mathrm{~g})$ in quartz vessels were cold-treated with nitric acid $\left(\mathrm{HNO}_{3} 20 \%\right.$; $20 \mathrm{~mL}$ ) and were left to stand for $24 \mathrm{~h}$. An extract obtained was filtered through Whatmann no. 42 filter paper into a plastic measuring vessel $(50 \mathrm{~mL})$, and after adding an internal standard solution (yttrium; $20 \mathrm{mg} \mathrm{L}^{-1}$ ), a $50-\mathrm{mL}$ mixture was made using deionized water and was subjected to instrumental analysis. Two blank digests were run with every set of the 15 soil samples.

$\mathrm{Ag}, \mathrm{Al}, \mathrm{Ba}, \mathrm{Ca}, \mathrm{Cd}, \mathrm{Co}, \mathrm{Cu}, \mathrm{Cr}, \mathrm{Fe}, \mathrm{K}, \mathrm{Mg}, \mathrm{Mn}, \mathrm{Na}, \mathrm{Ni}$, $\mathrm{P}, \mathrm{Pb}, \mathrm{Rb}, \mathrm{Sr}$, and $\mathrm{Zn}$ were determined by inductively coupled plasma optical emission spectroscopy (Optima 2000 DV, PerkinElmer, USA), and the yttrium was used as internal standard (Brzostowski et al. 2009).

These methods of metallic element measurements were validated and controlled for several occasions, and analyses were made of officially certified reference materials: International Atomic Energy Agency (IAEA) 359 cabbage leaves; and these from participating international calibration trials: GEMS/Food Euro proficiency testing exercise, the IAEA 338 proficiency test of trace elements in lichen, the Aquacon Project 9 soil analysis (European Commission Environment Institute), and oriental tobacco leaves (CTAOTL-1), tea leaves (INTC-TL-1), and Polish herbal blend (INCT-MPH-2) by the Institute of Nuclear Chemistry and Technology in Warsaw, Poland (Brzostowski et al. 2009, 


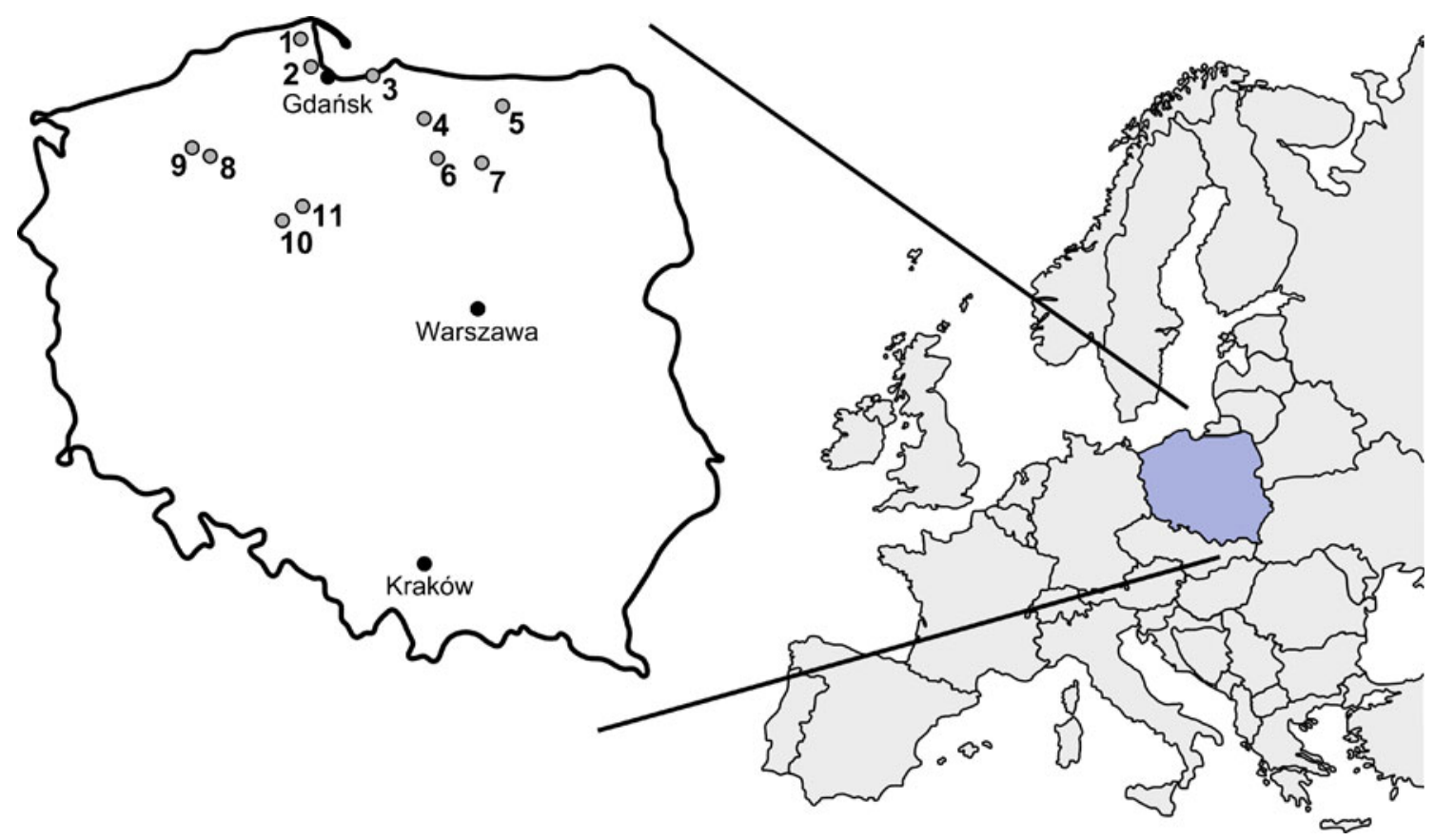

Fig. 1 Location of the sampling sites of Parasol Mushrooms. Darżlubska Forest (1), Trójmiejski Park Krajobrazowy (2), Mierzeja Wiślana (3), Morag and Łukta (4), Kętrzyn (5), Olsztynek (6), Szczytno (7), Czarne (8), Szczecinek (9), Bydgoszcz (10), and Rafa (11)

2011a, b; Chudzyński and Falandysz 2008). Discrepancies between certified values and concentrations quantified were below $10 \%$. Duplicates and blanks followed with every set of ten mushrooms or soil samples examined. For blank samples, no major interferences were found for the element quantified. Limits of detection for $\mathrm{Ag}, \mathrm{Al}, \mathrm{Ba}, \mathrm{Ca}, \mathrm{Cd}, \mathrm{Co}$, $\mathrm{Cu}, \mathrm{Cr}, \mathrm{Fe}, \mathrm{K}, \mathrm{Mg}, \mathrm{Mn}, \mathrm{Na}, \mathrm{Ni}, \mathrm{P}, \mathrm{Pb}, \mathrm{Rb}, \mathrm{Sr}$, and $\mathrm{Zn}$ were between 0.01 and $0.10 \mu \mathrm{g} \mathrm{g}^{-1}$ dry weight (dw). Coefficients of variation for these measurements on routine runs were well below $10 \%$.

Details on the methodology of mercury determination in fungal materials and soils by cold vapor atomic absorption spectroscopy were given in other reports (Falandysz 1990; Falandysz and Chwir 1997). For mercury, the method limit of detection was $0.005 \mu \mathrm{g} \mathrm{g}^{-1} \mathrm{dw}$. Data on total mercury in these mushrooms and soils were reported elsewhere (Falandysz et al. 2007a; Falandysz and Gucia 2008). In Table 1 , the median values of mercury concentration in the cap, which were used for risk assessment, are cited.

Mineral constituent uptake rate from the soil to fruiting bodies was assessed using the common concept of transfer factor that is commonly also expressed as an enrichment factor or BCF, which is simply the mushroom's constituent concentration divided by the soil (or other substratum media) mineral constituent concentration.

All data produced were statistically treated to find possible statistically significant differences between the variables with the aid of the nonparametric tests: KruskalWallis and Mann-Whitney $U$, principal component analysis (PCA), and cluster analysis (CA) (Figs. 2, 3 and 4; online resource, Figs. A.2-A.5). The computer software package Statistica version 8.0 used was for statistical analysis of data.

\section{Results and discussion}

\subsection{Macroelements (K, P, Mg, Ca, Na)}

Potassium Both the caps and stipes of Parasol Mushrooms can be considered rich in K. Good sources of $\mathrm{K}$ for biota are the caps of Parasol Mushrooms. The median concentrations varied in the caps between 25 and $47 \mathrm{mg} \mathrm{g}^{-1} \mathrm{dw}$ for the sites surveyed. These values show a certain degree of variability ( $p<0.01$; Mann-Whitney $U$ test) in the supplementation of caps with $\mathrm{K}$, when considering their use as food. Caps are characterized by a greater content of $\mathrm{K}$ compared to stipes. The median values of cap to stipe $\mathrm{K}$ concentration quotient $\left(Q_{\mathrm{C} / \mathrm{S}}\right)$ for these sites were between 1.1 and 2.1, and the maximum value in a single specimen was 5.2. Nevertheless, both the caps and stipes of Parasol Mushrooms are highly enriched with $\mathrm{K}$ in relation to its content in soil, where the median values for the 11 sites varied between 0.074 and $0.25 \mathrm{mg} \mathrm{g}^{-1} \mathrm{dw}$ (Table 1). The $\mathrm{BCF}$ median values of $\mathrm{K}$ for the caps in this study were between 120 and 500, and up to 1,100 in a single cap and up to 650 in a single stipe (online resource, Table A.1).

Phosphorous In soil, the median values of $\mathrm{P}$ were between 0.13 and $0.28 \mathrm{mg} \mathrm{g}^{-1} \mathrm{dw}$. An absolute concentration value 


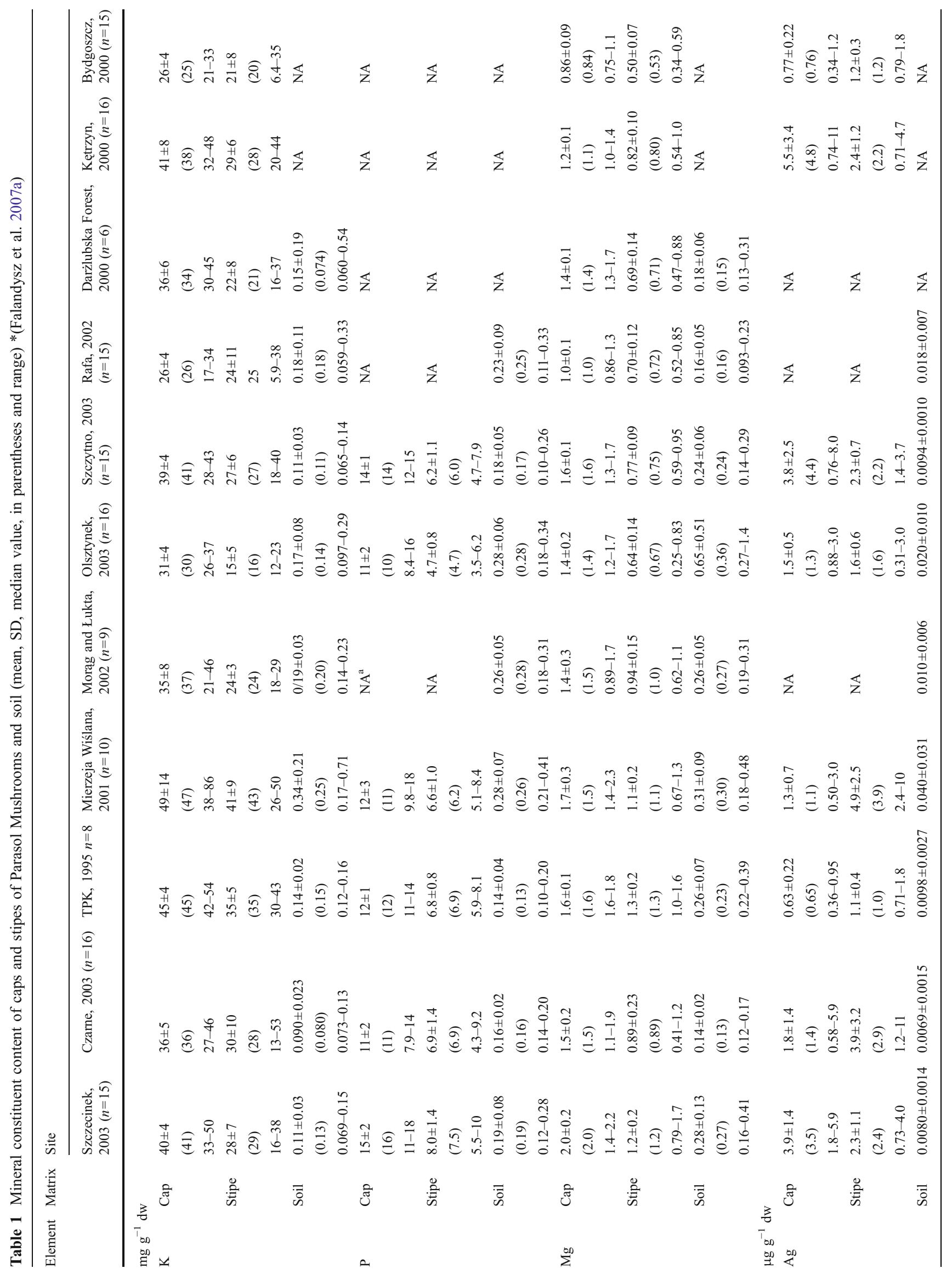




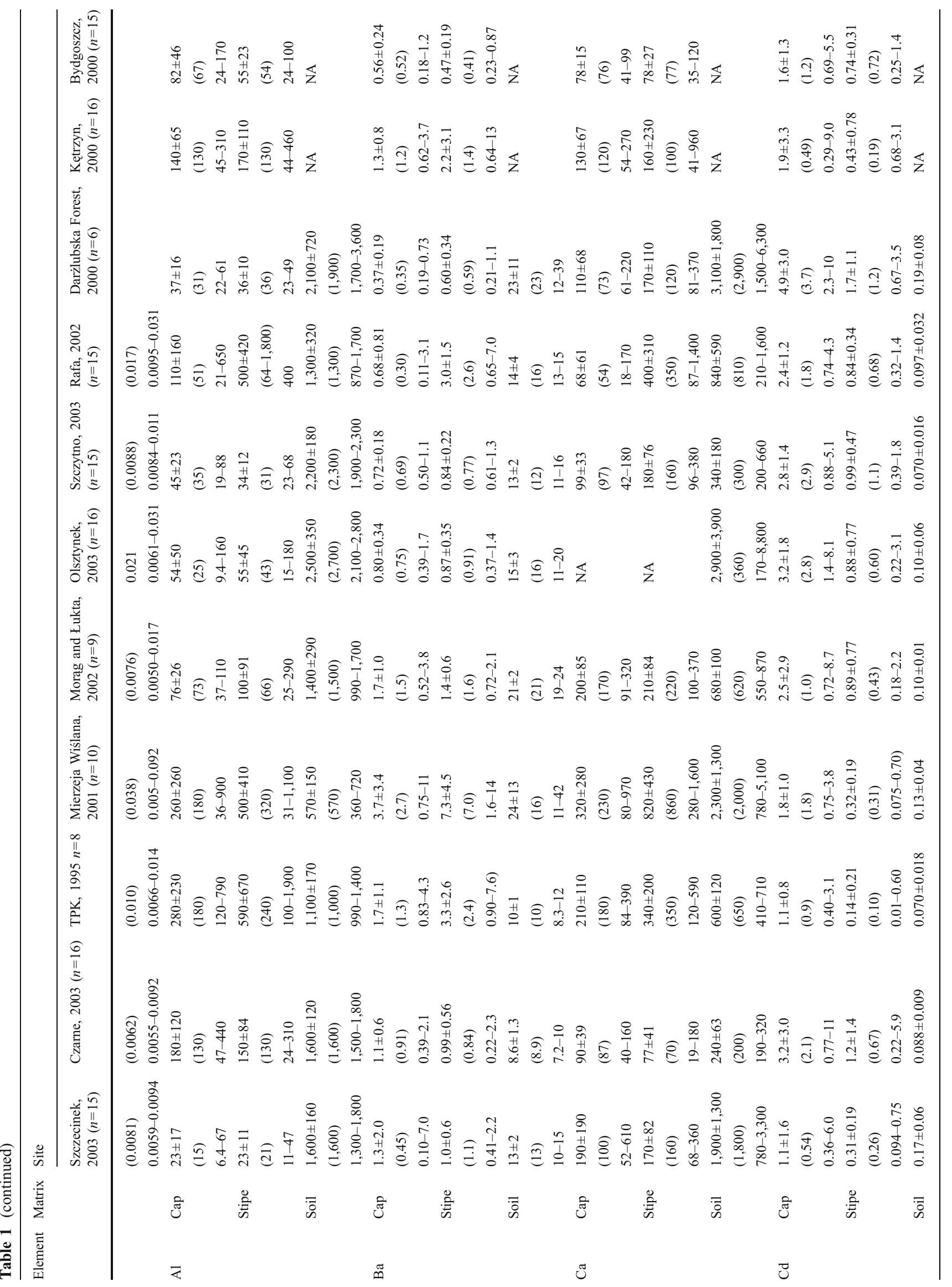




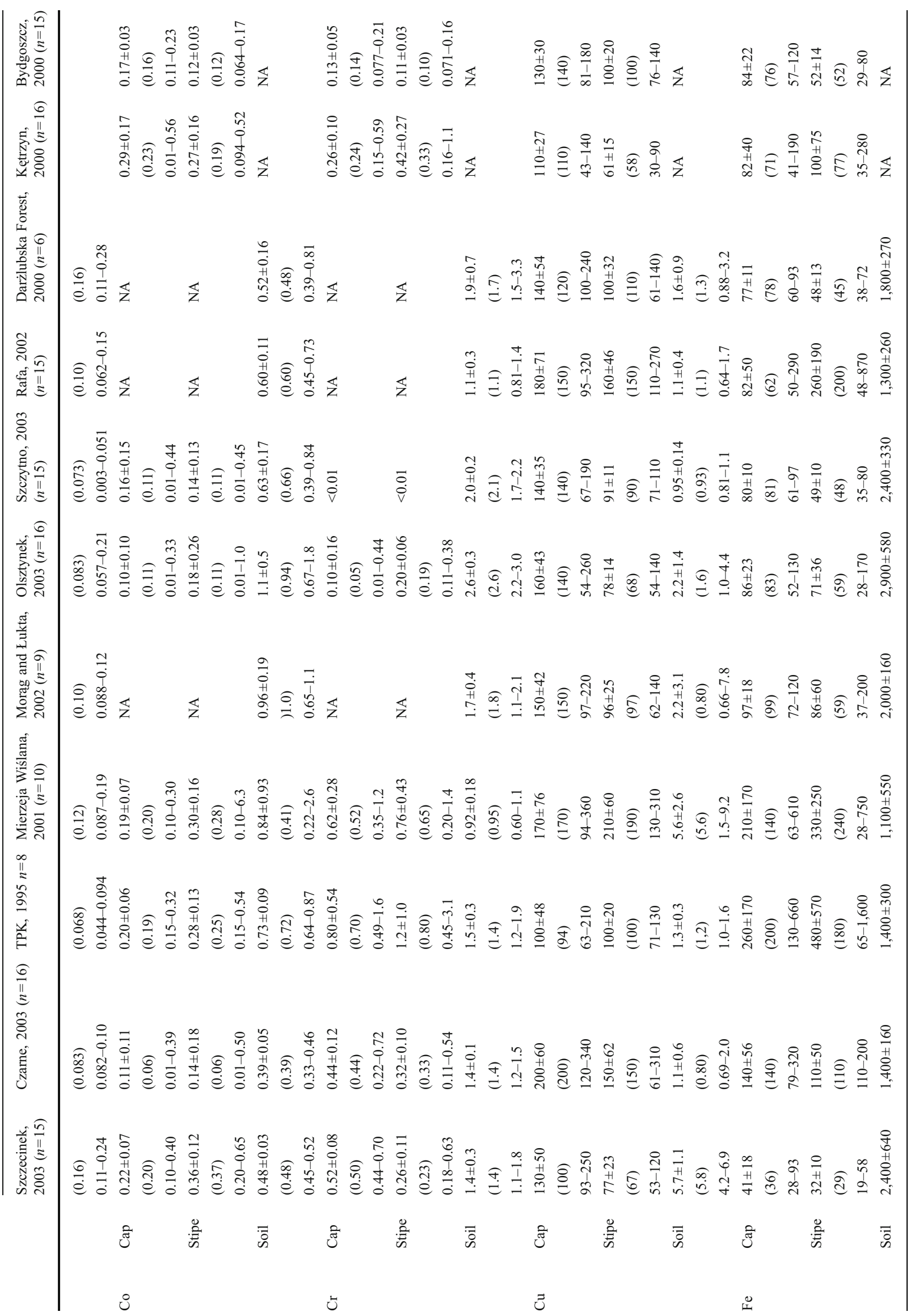




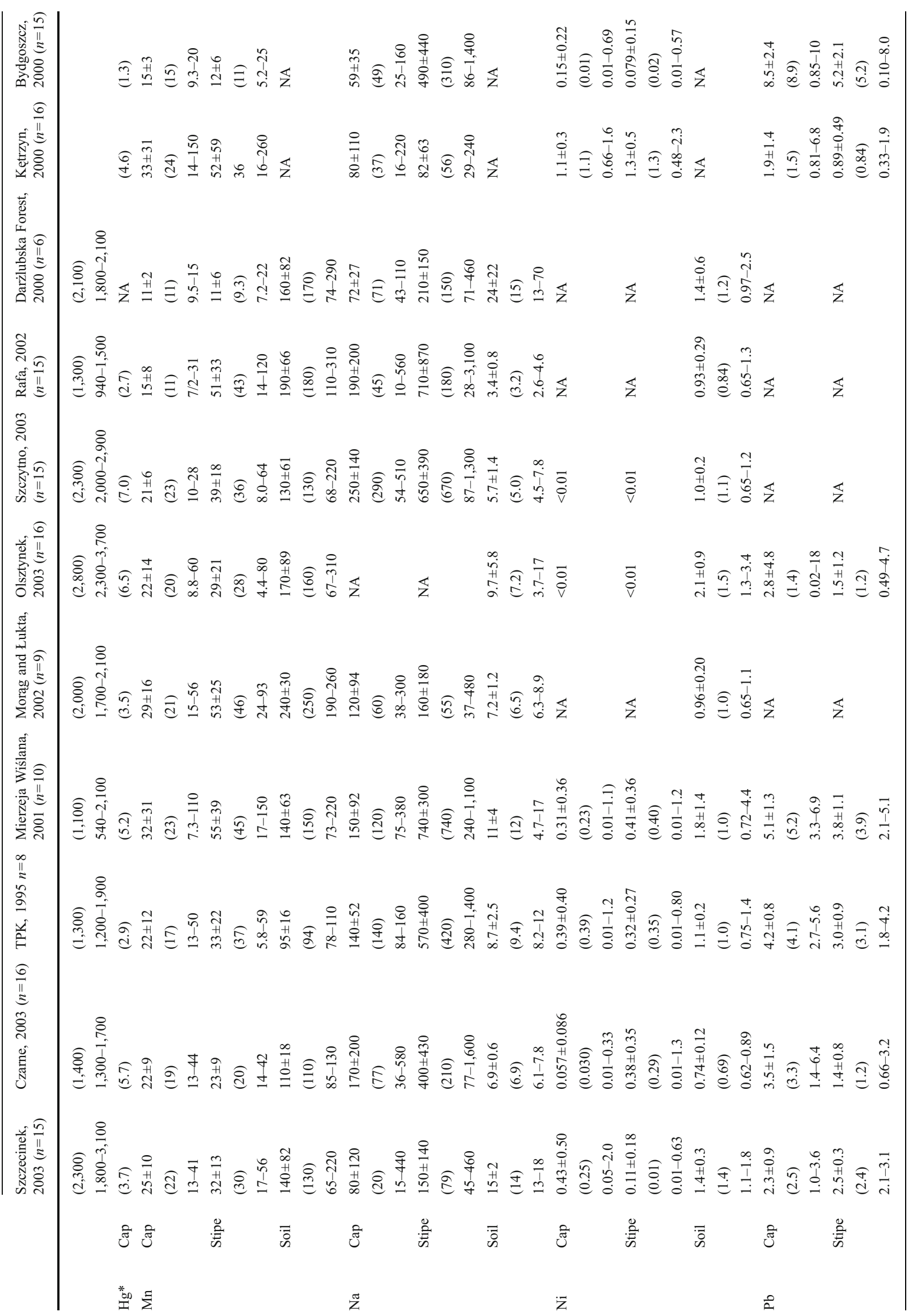




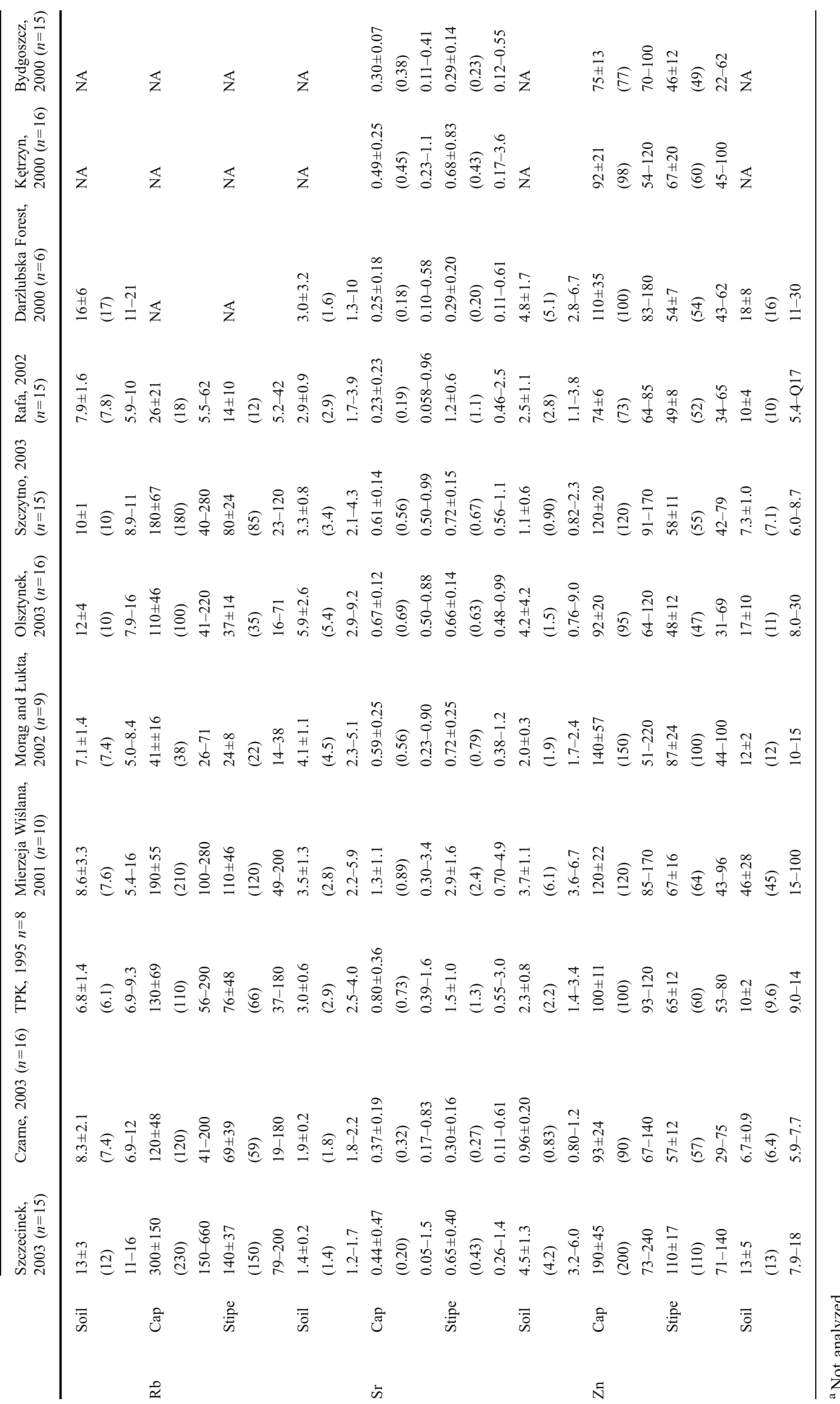


Fig. 2 Plot of loadings (unrotated) based on the concentration of metallic elements in caps (a) and stipes (b) of Parasol Mushrooms in the space of the first and second factors

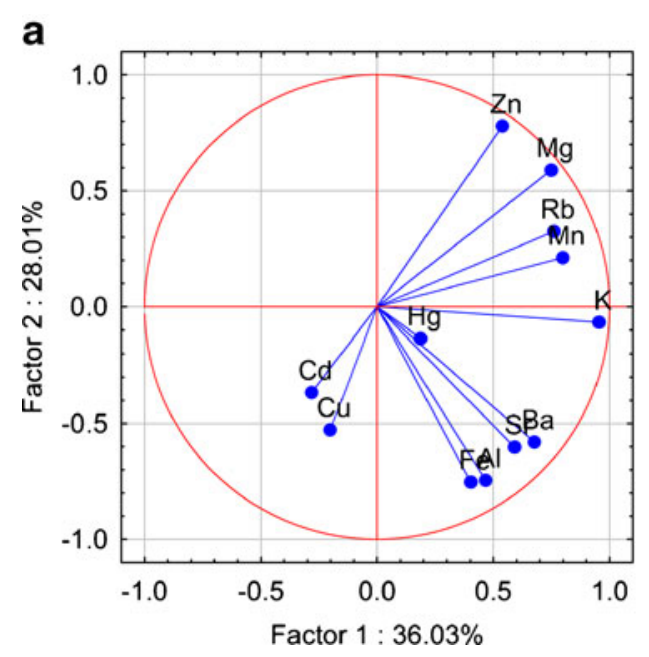

between the stands per site usually varied twofold and maximally up to threefold for one site. For all stands, this variation was around fourfold, i.e., were $0.093-0.41 \mathrm{mg} \mathrm{g}^{-1}$ dw. P occurred in the caps of Parasol Mushrooms at six sites between 8.4 and $18 \mathrm{mg} \mathrm{g}^{-1} \mathrm{dw}$, and the median values were between 10 and $16 \mathrm{mg} \mathrm{g}^{-1} \mathrm{dw}$. These caps, which are nearly twice more abundant in $\mathrm{P}$ compared to stipes and medians of $Q_{\mathrm{C} / \mathrm{S}}$, were between 1.7 and 2.3 and having a total range from 1.1 to 3.1. This mushroom assimilates $\mathrm{P}$ well from the surrounding substratum. The values of BCF of $\mathrm{P}$ and single caps were between 23 and 150, while medians varied significantly $(45-100 ; p<0.01)$ between the sites (online resource, Table A.1).

Magnesium Soil Mg was found at the median concentrations, varying between 0.13 and $0.36 \mathrm{mg} \mathrm{g}^{-1} \mathrm{dw}$, and for single stands, usually $<0.50 \mathrm{mg} \mathrm{g}^{-1} \mathrm{dw}$. Caps contained $\mathrm{Mg}$ at a relatively narrow concentration range with the median values varying between 1.0 and $2.0 \mathrm{mg} \mathrm{g}^{-1} \mathrm{dw}$ (total, $0.75-$ $2.3 \mathrm{mg} \mathrm{g}^{-1} \mathrm{dw}$ ). $\mathrm{Mg}$ in caps was from 1.3 to 2.1 in excess

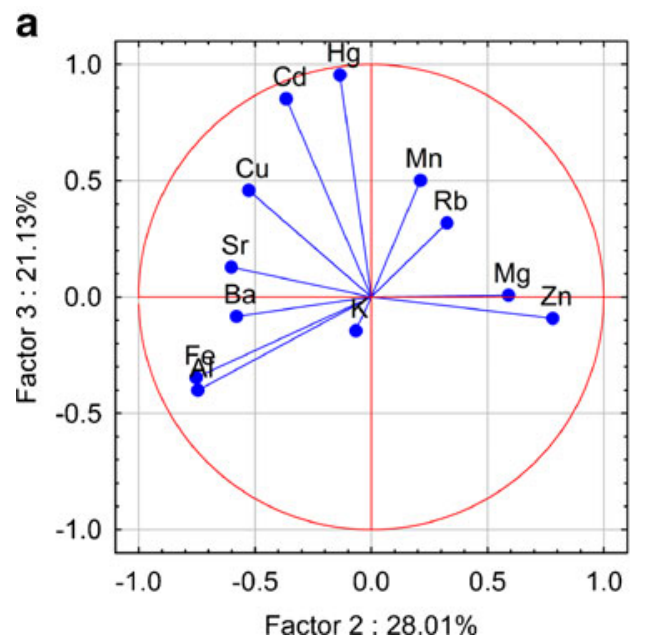

b

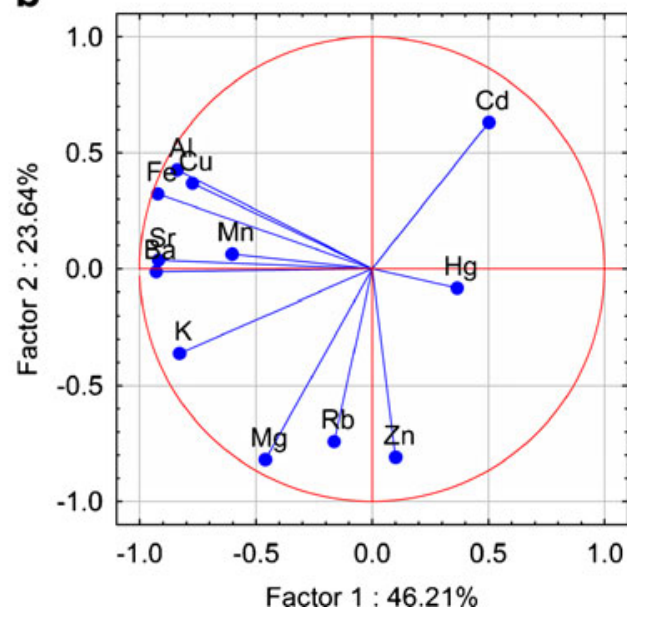

(median values), when compared to stipes (total $Q_{\mathrm{C} / \mathrm{S}}$ range from 0.99 to 5.5). This, essentially, to fungi and animal metal, is well taken up by Parasol Mushrooms and is sequestered in its caps (median BCF values per site varied between 3.3 and 11; total 0.86-14) and stipes (median BCF values per site varied between 0.92 and 6.3 ; online resource, Table A.1).

Calcium Soils varied in its content of Ca more than the other macroelements determined. The median values of $\mathrm{Ca}$ concentrations varied between 620 and $2,900 \mu \mathrm{g} \mathrm{g}^{-1} \mathrm{dw}$ soil at six sites and were much less, i.e., between 200 and $360 \mu \mathrm{g} \mathrm{g}^{-1}$ $\mathrm{dw}$, at three other sites (Table 1). The caps and stipes of this species are relatively abundant in $\mathrm{Ca}$, and the median concentration values varied between 54 and $230 \mu \mathrm{g} \mathrm{g}^{-1} \mathrm{dw}$ and 70 and $860 \mu \mathrm{g} \mathrm{g}^{-1} \mathrm{dw}$, respectively. For most of the sites surveyed, the stipes were richer in Ca compared to the caps, and the median values of $Q_{\mathrm{C} / \mathrm{S}}$ were between 0.19 and 1.3. In terms of bioconcentration concept, $\mathrm{Ca}$ is excluded in Parasol Mushrooms. The median BCF values of this element in

b

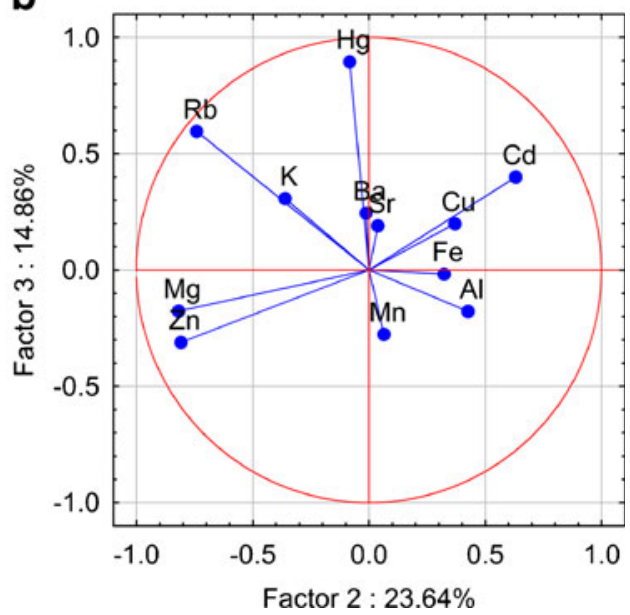

Fig. 3 Plot of loadings (unrotated) based on the concentration of metallic elements in caps (a) and stipes (b) of Parasol Mushrooms in the space of the second and third factors 
Fig. 4 Plot of loadings (unrotated) based on the concentration of metallic elements in caps (a) and stipes (b) of Parasol Mushrooms in the space of the first and third factors

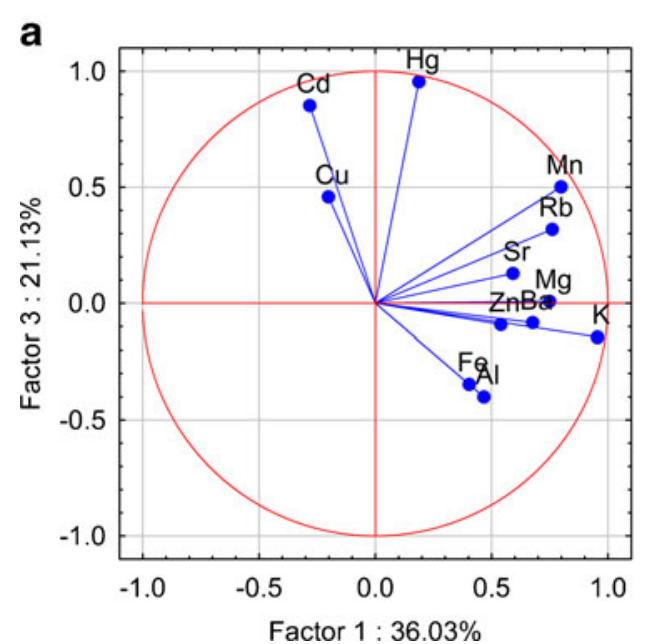

fruiting bodies at the sites surveyed varied between 0.036 and 0.36 for the caps and between 0.047 and 0.62 for the stipes (online resource, Table A.1).

Sodium This metal occurred in the soil substratum of Parasol Mushrooms with a median concentration varying between 3.2 and $15 \mu \mathrm{g} \mathrm{g}^{-1} \mathrm{dw}$. Apart from one site, the soil in the other sites contained $\mathrm{Na}$ in median concentration $\geq 5.0 \mu \mathrm{g} \mathrm{g}^{-1} \mathrm{dw}$ (Table 1). The stipes were usually more abundant in $\mathrm{Na}$ than the caps, and the median concentration values were between 55 and $670 \mu \mathrm{g} \mathrm{g}^{-1} \mathrm{dw}$ and 20 and $290 \mu \mathrm{g} \mathrm{g}^{-1} \mathrm{dw}$, respectively. For the Morag and Lukta (4) sites, the caps and stipes had the same $\mathrm{Na}$ content on average. In other sites, the median values of $Q_{\mathrm{C} / \mathrm{S}}$ were between 0.14 and 0.49 . Accordingly, due to highly variable soil and mushroom $\mathrm{Na}$ content, the assessed potential of Parasol Mushrooms to bioconcentrate this element varied between the sites. The median values of BCF were between 1.4 and 44 for caps and between 5.3 and 110 for stipes (online resource, Table A.1).

\subsection{Essential trace metals $(\mathrm{Cu}, \mathrm{Fe}, \mathrm{Mn}, \mathrm{Zn})$}

Copper Soil $\mathrm{Cu}$ content was around $1.0 \mu \mathrm{g} \mathrm{g} \mathrm{g}^{-1} \mathrm{dw}$ in most of the sites examined, and in the Szczecinek (9) and Mierzeja Wiślana (3) sites, the median values were 5.8 and $5.6 \mu \mathrm{g} \mathrm{g}^{-1} \mathrm{dw}$. Both the caps and stipes of Parasol Mushrooms in forested sites of Northern Poland are rich in $\mathrm{Cu}$ - the median values were between 94 and $200 \mu \mathrm{g} \mathrm{g}^{-1}$ $\mathrm{dw}$ in caps and between 58 and $150 \mu \mathrm{g} \mathrm{g}^{-1} \mathrm{dw}$ in stipes. Depending on the site surveyed, the median values of $Q_{\mathrm{C} / \mathrm{S}}$ were between 0.81 and 1.8. $\mathrm{Cu}$ is highly enriched in Parasol Mushrooms. The median values of $\mathrm{Cu}$ BCF for caps at the sites with relatively small soil $\mathrm{Cu}$ concentration were between 70 and 220, while 22 and 27 were in two sites mentioned, where soil is relatively rich in this element (Table 1; online resource, Table A.1). These differences suggest good and active regulation of $\mathrm{Cu}$ uptake and sequestration in maturating fruiting bodies, and this happens according to the physiological needs of Parasol Mushrooms, when emerging at the background (uncontaminated with $\mathrm{Cu}$ and other metals) areas.

Iron This metal is abundant in the soil substratum to Parasol Mushrooms. Its median concentration values varied for the sites between 1,100 and 2,900 $\mu \mathrm{g} \mathrm{g}^{-1} \mathrm{dw}$. These absolute concentration data noted for $\mathrm{Fe}$ in the top layer of the soil are of the same order of magnitude as $\mathrm{Ca}$, while the caps and stipes of the mushroom are more abundant in $\mathrm{Ca}$ than $\mathrm{Fe}$, on average. In caps and stipes, Fe occurred in the median concentrations between 36 and $200 \mu \mathrm{g} \mathrm{g}^{-1} \mathrm{dw}$ and 29 and $200 \mu \mathrm{g} \mathrm{g}^{-1} \mathrm{dw}$, respectively. These concentrations varied largely between the specimens - in caps, between 41 and $660 \mu \mathrm{g} \mathrm{g}^{-1} \mathrm{dw}$ and in stipes, between 19 and $600 \mu \mathrm{g} \mathrm{g}^{-1} \mathrm{dw}$. For some sampling sites, an abundance of Fe in Parasol Mushrooms was similar $(p>0.05)$ but for some varied highly $(p<0.01)$ (Table 1$)$. Fe was excluded in this species $(\mathrm{BCF}<1)$. The caps of Parasol Mushrooms usually contained $\mathrm{Fe}$ in greater concentration when compared to stipes, and the median value of $Q_{\mathrm{C} / \mathrm{S}}$ for most of the sites was from 1.2 to 1.6 and at two sites was 0.34 and 0.64 (online resource, Table A.1).

Manganese The soil substratum Mn concentrations varied between 94 and $250 \mu \mathrm{g} \mathrm{g}^{-1} \mathrm{dw}$ (median values), and the total range was from 67 to $310 \mu \mathrm{g} \mathrm{g}^{-1} \mathrm{dw}$. Mn, in terms of the bioconcentration/exclusion concept, is bio-excluded in Parasol Mushrooms. This is because the median BCF values, as calculated for caps and stipes of fruiting bodies from all the sites surveyed in this study, were $<0.2$ and $<0.3$, and the maximum values for two single samples were 0.89 and 0.86 , respectively (online resource, Table A.1). This mushroom is moderately abundant in Mn. The median values of $\mathrm{Mn}$ in Parasol Mushroom from the sites in Northern Poland varied 
between 11 and $24 \mu \mathrm{g} \mathrm{g}^{-1} \mathrm{dw}$ (total, 7.2-66 $\mu \mathrm{g} \mathrm{g}^{-1} \mathrm{dw}$ ) in caps and 9.3 and $46 \mu \mathrm{g} \mathrm{g}^{-1} \mathrm{dw}\left(4.4-260 \mu \mathrm{g} \mathrm{g}^{-1} \mathrm{dw}\right)$ in stipes (Table 1).

Zinc Soil Zn concentrations varied significantly $(p<0.01$; Mann-Whitney $U$ test) between some of the sites. The median values for $\mathrm{Zn}$ in soil in the eight sites varied between 6.4 and $16 \mu \mathrm{g} \mathrm{g}^{-1} \mathrm{dw}$ (total range, 5.9-30 $\mu \mathrm{g} \mathrm{g}^{-1}$ $\mathrm{dw})$. For the stands of Parasol Mushrooms in the Mierzeja Wiślana (3) site, the median value in soil was $45 \mu \mathrm{g} \mathrm{Zn} \mathrm{g}^{-1}$ $\mathrm{dw}$, which is significantly greater $(p<0.001$; Mann-Whitney $U$ test) than elsewhere in this survey. The Parasol Mushroom contains $\mathrm{Zn}$ in the caps in greater concentration than in the stipes, and the $Q_{\mathrm{C} / \mathrm{S}}$ values were between 1.5 and 2.0 per site (total range, 0.62-4.2). The median concentration values were between 73 and $200 \mu \mathrm{g} \mathrm{Zn} \mathrm{g}{ }^{-1} \mathrm{dw}$ (total, 64$240 \mu \mathrm{g} \mathrm{Zn} \mathrm{g}^{-1} \mathrm{dw}$ ) for caps and 47 and $110 \mu \mathrm{g} \mathrm{g}^{-1} \mathrm{dw}$ (total $22-140 \mu \mathrm{g} \mathrm{g}^{-1} \mathrm{dw}$ ) for stipes. This metal is moderately bioconcentrated in fruiting bodies, and the median $\mathrm{BCF}$ values were between 3.7 and 15 for caps and 1.8 and 7.7 for stipes (online resource, Table A.1).

These macro and trace metals of nutritional value occurred in the Parasol Mushroom's fresh caps (assuming 10\% dry weight) at the sites surveyed at the median concentrations (micrograms per gram wet weight (ww)) varying between 2,500 and 4,700 (K), 13 and $28(\mathrm{P}), 13$ and $36(\mathrm{Mg}), 62$ and $290(\mathrm{Ca}), 0.32$ and $1.5(\mathrm{Na}), 9.4$ and $20(\mathrm{Cu}), 3.6$ and 20 $(\mathrm{Fe}), 1.1$ and $2.4(\mathrm{Mn})$, and 4.7 and $10(\mathrm{Zn})$. Estimated, the essential mineral intake, resulting from the consumption of a 300 - or 500-g portion of cap from a particular site varied between 750 and 2,300 $\mathrm{mg} \mathrm{K}, 3.9-14 \mathrm{mg} \mathrm{P,} \mathrm{3.9-15} \mathrm{mg} \mathrm{Mg,}$ 19-140 mg Ca, 2.8-10 mg Cu, 1.1-10 mg Fe, 0.331.2 mg Mn, 1.4-5.0 mg Zn, and 96-750 $\mu \mathrm{g} \mathrm{Na.}$

\subsection{Some other trace metals ( $\mathrm{Ag}, \mathrm{Al}, \mathrm{Ba}, \mathrm{Co}, \mathrm{Cr}, \mathrm{Ni}, \mathrm{Rb}, \mathrm{Sr}$ )}

Silver This metal occurred in very small concentrations in the top layer of soil substrates to Parasol Mushroom but was very efficiently taken up and sequestered in fruiting bodies. The median values of $\mathrm{Ag}$ concentrations in soil varied among the sites between 0.0076 and $0.038 \mu \mathrm{g} \mathrm{g}^{-1}$ $\mathrm{dw}$. At no one single stand did the Ag content of soil exceed $0.1 \mu \mathrm{g} \mathrm{g}^{-1} \mathrm{dw}$ (Table 1). On the other hand, the fruiting bodies were relatively abundant in this metal, and the median values of $\mathrm{Ag}$ concentrations in caps varied between 0.065 and $4.8 \mu \mathrm{g} \mathrm{g}^{-1} \mathrm{dw}$ and in stipes between 1.0 and $3.9 \mu \mathrm{g} \mathrm{g}^{-1} \mathrm{dw}$. This efficient accumulation of $\mathrm{Ag}$ in relation to its very small abundance in soil resulted in high BCF, with the median values varying between 67 and 420 for caps and 85 and 440 for stipes. Ag was not uniformly distributed between the caps and stipes of fruiting bodies. At two sites, evidently, caps were more enriched in Ag when compared to stipes, and an opposite can be noted for some other sites (online resource, Table A.1).

Aluminum Soils from the Parasol Mushroom stands at the eight sites contained in the top layer $\mathrm{Al}$ in concentrations varying between 1,100 and $2,700 \mu \mathrm{g} \mathrm{g}^{-1} \mathrm{dw}$ (median values), and much less, i.e., $570 \mu \mathrm{g} \mathrm{g}^{-1} \mathrm{dw}$, was in the Mierzeja Wiślana (3) site which is localized near the Baltic Sea coast. This metal is bio-excluded in fruiting bodies by the Parasol Mushroom. Nevertheless, the median BCF value of Al for caps (0.62) and stipes (1.4) of the fruiting bodies at the Mierzeja Wiślana (3) site are evidently higher, when compared to the sites with soil more abundant in $\mathrm{Al}$ - the medians of $\mathrm{BCF}<0.3$ (online resource, Table A.1). This observation implies the better availability of Al to Parasol Mushroom, when $\mathrm{Al}$ is a less abundant component of the soil substratum, while there is no evidence on its essentiality to mushrooms. $\mathrm{Al}$, on average, is equally distributed between the caps and stipes of fruiting bodies, but some variations between specimens and sites can be noted (Table 1).

Barium The median values of $\mathrm{Ba}$ concentration of soil substrates varied in the sites between 8.9 and $23 \mu \mathrm{g} \mathrm{g}^{-1} \mathrm{dw}$ (total range from 7.2 to $42 \mu \mathrm{g} \mathrm{g}^{-1} \mathrm{dw}$ ). These concentrations are greater compared to that determined to closely related element strontium. The caps and stipes of fruiting bodies of Parasol Mushrooms, depending on the site of collection, varied in $\mathrm{Ba}$ content $(p<0.01)$. The median concentration values of $\mathrm{Ba}$ were between 0.30 and $1.3 \mu \mathrm{g} \mathrm{g}^{-1} \mathrm{dw}$ (total, 0.10 and $11 \mu \mathrm{g} \mathrm{g}^{-1} \mathrm{dw}$ ) in caps and between 0.41 and $7.0 \mu \mathrm{g} \mathrm{g}^{-1} \mathrm{dw}$ (total, 0.21 and $14 \mu \mathrm{g} \mathrm{g}^{-1}$ $\mathrm{dw}$ ) in stipes. These data show that $\mathrm{Ba}$, which is more or less equally distributed between the cap and stipe of fruiting bodies, is bio-excluded by Parasol Mushroom in fruiting bodies, and for both caps and stipes BCF was $<1$ (online resource, Table A.1).

Cobalt Soils in the sites surveyed contained Co in concentrations varying between 0.39 and $1.0 \mu \mathrm{g} \mathrm{g}^{-1} \mathrm{dw}$ (median values). Cobalt in fruiting bodies of Parasol Mushroom is a minor trace metal, and its median concentration values varied between 0.06 and 0.23 in caps and 0.06 and $0.37 \mu \mathrm{g} \mathrm{g}^{-1} \mathrm{dw}$ in stipes. In light of these data, Co was bio-excluded by Parasol Mushroom, and a value of BCF for this metal was $<0.5$ both in caps and stipes. The distribution of Co between the cap and stipe of the fruiting bodies was equal for mushrooms from most of the sites, but the range of median values of $Q_{\mathrm{C} / \mathrm{S}}$ was between 0.61 and 1.4 (online resource, Table A.1).

Chromium This metal occurred as trace compound in all soil substrates sampled. The median values of its concentrations varied for the sites between 0.95 and $2.6 \mu \mathrm{g} \mathrm{g}^{-1} \mathrm{dw}$, 
and the maximum concentration in a single stand was up to $3.3 \mu \mathrm{g} \mathrm{g}^{-1} \mathrm{dw}$. Cr was a minor trace metal in Parasol Mushroom in this study. The fruiting bodies at the sites surveyed contained $\mathrm{Cr}$ in the caps and stipes in concentrations between 0.14 and $0.70 \mu \mathrm{g} \mathrm{g}^{-1} \mathrm{dw}$ and 0.10 and $0.80 \mu \mathrm{g} \mathrm{g}^{-1} \mathrm{dw}$, respectively (median values). The median values of $Q_{\mathrm{C} / \mathrm{S}}$ in the case of $\mathrm{Cr}$ varied per site between 0.31 and 2.1. Since the BCF values of $\mathrm{Cr}$ were $<1$ for caps and stipes, this metal can be considered as bio-excluded in fruiting bodies by the Parasol Mushroom.

Nickel This element is one of the minor metallic elements determined in Parasol Mushrooms. Specimens collected at the Kętrzyn (5), Szczecinek (9), and Trójmiejski Park Krajobrazowy (2) sites from the northern region of Poland were more abundant $(p<0.05$; Mann-Whitney $U$ test $)$ in nickel $\left(1.1 \pm 0.3,0.43 \pm 0.50\right.$, and $0.39 \pm 0.40 \mu \mathrm{g} \mathrm{g}^{-1} \mathrm{dw}$ in caps and $1.3 \pm 0.5,0.32 \pm 0.27$, and $0.11 \pm 0.18 \mu \mathrm{g} \mathrm{g}^{-1} \mathrm{dw}$ in stipes, respectively) when compared to other sites surveyed (Table 1). Both the caps and stipes of Parasol Mushrooms from the Trójmiejski Park Krajobrazowy (2), Mierzeja Wiślana (3), and Kętrzyn (5) sites contain nickel in comparable concentrations, and the $Q_{\mathrm{C} / \mathrm{S}}$ value for this metal was $\sim 1$ (online resource, Table A.1). Nickel in the background areas is among the metallic elements that are bio-excluded by Parasol Mushroom $(\mathrm{BCF}<1$; online resource, Table A.1).

Rubidium Soil $\mathrm{Rb}$ content differed between some of the sites $(p<0.01$; Mann-Whitney $U$ test), and the median concentration values varied between 1.4 and $5.4 \mu \mathrm{g} \mathrm{g}^{-1} \mathrm{dw}$ (total range, $1.2-10 \mu \mathrm{g} \mathrm{g}^{-1} \mathrm{dw}$ ). The fruiting bodies contained $\mathrm{Rb}$ in the caps in concentrations around twice greater than in stipes (range of the median $Q_{\mathrm{C} / \mathrm{S}}$ values was from 1.4 to 3.1). The median values of $\mathrm{Rb}$ concentration in caps varied between 100 and $230 \mu \mathrm{g} \mathrm{g}^{-1} \mathrm{dw}$ for six sites and in stipes for these sites was between 35 and $150 \mu \mathrm{g} \mathrm{g}^{-1} \mathrm{dw}$. At the Morag/Lukta (4) and Rafa (11) sites, Rb abundance of fruiting bodies was much lower than elsewhere in this survey, i.e., in these two sites they contained 18 and $38 \mu \mathrm{g} \mathrm{g}^{-1} \mathrm{dw}$ in caps and 12 and $22 \mu \mathrm{g} \mathrm{g}^{-1} \mathrm{dw}$ in stipes, respectively. $\mathrm{Rb}$ is relatively well bioconcentrated by the Parasol Mushroom. The BCF median values in the fruiting bodies varied between 10 and 170 for the caps and 5.1 and 97 for the stipes (online resource, Table A.1).

Strontium The sites varied in $\mathrm{Sr}$ content in the soil substratum to Parasol Mushroom $(p<0.01)$, and the median values were between 0.83 and $5.1 \mathrm{\mu g} \mathrm{g}^{-1} \mathrm{dw}$ (total range, 0.76$6.1 \mu \mathrm{g} \mathrm{g}^{-1} \mathrm{dw}$ ). Sr is bio-excluded by this mushroom in fruiting bodies, and the median values of $\mathrm{BCF}$ of this metal for caps and stipes were $<1$. Hence, $\mathrm{Sr}$ content in fruiting bodies of Parasol Mushroom was low. The median concen- tration values in caps varied between 0.18 and $0.89(0.05-$ 3.4) and in stipes between 0.23 and $2.4(0.11-4.9) \mu \mathrm{g} \mathrm{g}^{-1} \mathrm{dw}$.

\subsection{Toxic metals $(\mathrm{Cd}, \mathrm{Pb}, \mathrm{Hg})$}

Cadmium The median values of $\mathrm{Cd}$ concentration in soil substrates to Parasol Mushroom at the sites surveyed varied between 0.068 and $0.16 \mu \mathrm{g} \mathrm{g}^{-1} \mathrm{dw}$, and the maximum value per stand was $0.28 \mu \mathrm{g} \mathrm{g}^{-1} \mathrm{dw}$. This mushroom is able to efficiently uptake $\mathrm{Cd}$ from the surrounding environment and sequester in fruiting bodies. The BCF for caps was between 3.3 and 36 and up to 140 per single cap (online resource, Table A.1). The median concentrations of $\mathrm{Cd}$ in caps were between 0.49 and $3.7 \mu \mathrm{g} \mathrm{g}^{-1} \mathrm{dw}$ and in stipes between 0.10 and $1.2 \mu \mathrm{g} \mathrm{g}^{-1} \mathrm{dw}$. Caps were at least twice more abundant in cadmium than stipes, on average, and up to 22 per single cap (Table 1).

Cadmium in the flesh of edible wild mushrooms is among the toxic substances of concern. In the European Union, the maximum level of cadmium in cultivated mushrooms (Oyster Mushroom Pleurotus ostreatus, Champignon Mushroom Agaricus bisporus, and Shiitake Lentinus edodes) is $0.20 \mu \mathrm{g} \mathrm{g}^{-1}$ fresh weight (fw) (equivalent to $2.0 \mu \mathrm{g} \mathrm{g}^{-1} \mathrm{fw}$, assuming $90 \%$ moisture) and for other fungi is $1.0 \mu \mathrm{g} \mathrm{g}^{-1} \mathrm{fw}$ $\left(10 \mu \mathrm{g} \mathrm{g}^{-1} \mathrm{dw}\right)$ (EU 2008). In light of the European Commission regulations on $\mathrm{Cd}$, the median values of cadmium concentrations in caps were well below $10 \mu \mathrm{g} \mathrm{g}^{-1} \mathrm{dw}$. In three of 141 caps examined, $\mathrm{Cd}$ concentration was between 9.0 and $11 \mu \mathrm{g} \mathrm{g}^{-1} \mathrm{dw}$ (Table 1). The provisional tolerable weekly intake (PTWI) for cadmium is $7 \mu \mathrm{g} \mathrm{kg}^{-1}$ body weight (bw) (equivalent to $1 \mu \mathrm{g} \mathrm{kg}^{-1}$ bw per day), and a tolerable weekly intake (TWI) of $2.5 \mu \mathrm{g} \mathrm{kg}^{-1}$ bw (equivalent to $0.36 \mu \mathrm{g} \mathrm{kg}^{-1}$ bw per day) (European Food Safety Authority EFSA 2009; World Health Organization WHO 1989). Estimated cadmium intake resulting from the consumption of a $300-$ or $500-\mathrm{g}$ portion of caps is 4.7-111 and 24.5-185 $\mu \mathrm{g}$ (median Cd content between 0.49 and $0.37 \mu \mathrm{g} \mathrm{g}^{-1}$ wet weight, assuming the water content is $90 \%$ ), and what is equivalent to $0.073-1.85$ and $0.41-3.1 \mu \mathrm{g} \mathrm{kg}^{-1}$ body weight (an adult of $60 \mathrm{~kg} \mathrm{bw}$ ). As mentioned earlier, caps of Parasol Mushrooms can be large in size and are highly valued by the mushrooming fanciers, and all specimens found are collected. No doubt, some individuals from the local countryside populations and the cottage house owners or the camp tourists, temporarily, eat them even several times in a week in the summer time. Hence, in a good "mushroom" year an abundance of this species will lead to a short time ( 2 weeks to up to 2 months) exposure of fanciers to elevated $\mathrm{Cd}$ doses that exceed the PTWI and TWI recommendations.

The assessed doses show that a single meal composed of 300 - or $500-\mathrm{g}$ caps at some sites surveyed will result in 
exceeding the PTWI and revised TWI rates for Cd. A few studies on bioavailability of $\mathrm{Cd}$ from the mushroom meals gave results leading to an opposite conclusions. In two studies (Diehl and Schlemmer 1984; Schellmann et al. 1980) absorption of $\mathrm{Cd}$ was below $10 \%$, while much more effective in three other studies (Lind et al. 1995; Mitra et al. 1995; Seeger et al. 1986). Hence, Cd in caps of Parasol Mushrooms at some of the sites surveyed might be of concern for consumers, if eaten frequently by an individual in the mushrooming season.

Lead $\mathrm{Pb}$ is bio-excluded by Parasol Mushroom $(\mathrm{BCF}<1)$. Soil contained $\mathrm{Pb}$ in concentrations varying between 6.1 and $17 \mu \mathrm{g} \mathrm{g}^{-1} \mathrm{dw}$ (medians), while up to $21 \mu \mathrm{g} \mathrm{g}{ }^{-1} \mathrm{dw}$ was per a single stand (online resource, Table A.1). For caps, $\mathrm{Pb}$ concentrations varied between 1.4 and $8.9 \mu \mathrm{g} \mathrm{g}^{-1} \mathrm{dw}$ (medians) per site. Caps were from 0.86 to $3.1\left(Q_{\mathrm{C} / \mathrm{S}}\right)$ more abundant in $\mathrm{Pb}$ than stipes, which contained between 0.84 and $5.2 \mu \mathrm{g} \mathrm{g}^{-1} \mathrm{dw}$ (medians). In the case of $\mathrm{Pb}$, the maximum level permitted by EU regulation in cultivated mushrooms (Oyster Mushroom, Champignon Mushroom, and Shiitake) is $0.3 \mu \mathrm{g} \mathrm{g}^{-1}$ fw (3.0 $\mu \mathrm{g} \mathrm{g}^{-1} \mathrm{dw}$; assuming $90 \%$ moisture) (EU 2008). $\mathrm{Pb}$ content in other fungi (assuming that other than the mentioned three species in the case of cultivated mushrooms as well as all edible species of wild-grown mushrooms) is not regulated by the EU law. The acceptable daily intake of lead for adults is between 210 and $250 \mu \mathrm{g}$ per day and 1,500 and $1,750 \mu \mathrm{g}$ per week or 25 and $29 \mu \mathrm{g}$ per kg bw weekly for an individual of $60 \mathrm{~kg}$ bw (World Health Organization WHO 1993). Estimated $\mathrm{Pb}$ intake from consumption of a 300- or 500-g cap was 42-267 and 70-445 $\mu \mathrm{g}$ per meal, respectively. These values are based on the median concentrations of $\mathrm{Pb}$ found in caps in this survey. Hence, the $\mathrm{Pb}$ intake rates show a cause for concern associated with $\mathrm{Pb}$ resulting from the consumption of between 300- and 500-g caps daily, on a frequent basis in the mushrooming season but at some of the sites surveyed only.

Mercury The BCF values of mercury in the literature have been reported to be in the range from $16 \pm 6$ to $220 \pm 110$ (total range from 0.52 to 470 ) for the caps and from $7.6 \pm$ 2.6 to $130 \pm 96$ (total range from 0.52 to 340 ) for the stipes (Falandysz et al. 2007a; Falandysz and Gucia 2008). The PTWI for $\mathrm{Hg}$ is $300 \mu \mathrm{g}$ (equivalent to 5 or $0.7 \mu \mathrm{g} \mathrm{kg}^{-1} \mathrm{bw}$ per day), and a reference dose is $0.3 \mu \mathrm{g} \mathrm{kg}^{-1}$ bw per day (JECFA 1978; US EPA 2005). Parasol Mushrooms contained $\mathrm{Hg}$ in caps in median concentration varying for the sites surveyed between 1.3 and $7.0 \mu \mathrm{g} \mathrm{g}^{-1} \mathrm{dw}(0.13$ and

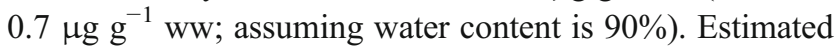
$\mathrm{Hg}$ intake resulting from the consumption of 300- or 500-g portions of caps is $39-210$ and $65-350 \mu \mathrm{g}$ and what is equivalent to $0.65-3.5$ and $1.1-5.8 \mu \mathrm{g} \mathrm{kg}^{-1}$ bw (an adult of
$60 \mathrm{~kg} \mathrm{bw})$. Also, $\mathrm{Hg}$ in caps of Parasol Mushrooms for some of the sites surveyed might be of concern, if eaten by fanciers frequently in the mushrooming season.

\subsection{Principal component analysis and cluster analysis of data}

PCA enables a reduction in data and description of a given multidimensional system by means of a small number of new variables. PCA with no rotation was applied to data set. In this respect, loadings $>0.90$ are typically regarded as excellent and $<0.70$ very poor. The number of significant components, initial eigenvalues, total variance (percent), and factor loadings were explained by using an unrotate method and are tabulated in Table A.2 (online resource). The results of PCA for data sets indicate three factors explaining approximately $85 \%$ of the total variance for caps and $84 \%$ for stipes. For caps, the first principal component (PC1) comprised $\mathrm{K}, \mathrm{Mg}, \mathrm{Mn}$, and $\mathrm{Rb}$ with high positive loadings (>0.75) and explains $36 \%$ of the variance. In the case of stipes, PC1 is strongly influenced by negatively correlated variables describing $\mathrm{K}, \mathrm{Al}, \mathrm{Ba}, \mathrm{Cu}, \mathrm{Fe}, \mathrm{Sr}$ and explains $46 \%$ of the variance. For caps and stipes, the component $\mathrm{PC} 2$ explained $28 \%$ and $24 \%$ of the variance, respectively, and it was made up of $\mathrm{Al}, \mathrm{Fe}, \mathrm{Zn}$ for caps and $\mathrm{Mg}, \mathrm{Rb}, \mathrm{Zn}$ for stipes. With the third principal component (PC3), associated are positively correlated $\mathrm{Cd}$ and $\mathrm{Hg}$ for caps, and for stipes associated is positively correlated Hg. In the case of caps, the first principal componentspanning the greater amount of variance, includes $\mathrm{K}, \mathrm{Mg}$, $\mathrm{Mn}$, and $\mathrm{Rb}$. This association may suggest that the source of these metals is natural, i.e., not related to human activities in the studied areas. The second factor groups were $\mathrm{Al}, \mathrm{Fe}$, and $\mathrm{Zn}$. The positive loading for $\mathrm{Zn}$ might indicate that this metal is controlled by a different geochemical mechanism or it has a different source in analyzed regions. The concentrations of $\mathrm{Cd}$ and $\mathrm{Hg}$ in caps of Parasol Mushrooms appear in the PC3 and could be related to the anthropogenic sources such as industry, traffic, or agriculture. In Figs. 2, 3, and 4 the interdependences among the elements in the factor space as a PCA plot are shown graphically. As can be deduced from these figures, some metallic elements tend to cluster together. For example, in caps, the pair $\mathrm{Mn}-\mathrm{Rb}$ cluster together (associated with $\mathrm{PC} 1$ ), and in stipes, negatively correlated pairs $\mathrm{Sr}-\mathrm{Ba}$ and $\mathrm{Al}-\mathrm{Fe}-\mathrm{Cu}$ cluster together. In caps, the pair $\mathrm{Al}-$ $\mathrm{Fe}$ is separated, and in stipes, $\mathrm{Mg}-\mathrm{Zn}$ tends to cluster together and is associated with PC2. In caps, the pair $\mathrm{Cd}-$ $\mathrm{Hg}$ tends to cluster together when associated with PC3. Metals such as $\mathrm{K}, \mathrm{Mg}, \mathrm{Zn}$ for caps and $\mathrm{K}, \mathrm{Rb}$ for stipes are separated from other metals. A projection of Parasol Mushroom trace metals data set on the principal components plane allowed to visualize contribution of the 
particular groups of metallic elements to the specimens spread (online resource, Figs. A.1-A.3). In spite of that, the elements such as $\mathrm{K}, \mathrm{Mg}, \mathrm{Mn}, \mathrm{Rb}$ in the caps and $\mathrm{K}, \mathrm{Al}, \mathrm{Ba}$, $\mathrm{Cu}, \mathrm{Fe}, \mathrm{Sr}$ in the stipes introduced the greatest variance in mineral composition; only the samples from the MW site could be separated based on these criteria (online resource, Figs. A.1 and A.3). Parasol Mushroom at the SZ site clearly overwhelmed others due to the $\mathrm{Zn}$ content in caps and stipes, and $\mathrm{Mg}, \mathrm{Rb}$ content in stipes. A great variability of $\mathrm{Al}$ and $\mathrm{Fe}$ content is noted for caps from the MW area (Fig. 7). The principal components 2 and 3 planes (online resource, Fig. A.2) did indicate specimens from the SZ site as more contaminated with $\mathrm{Hg}$.

To examine trace element clustering and to evaluate similarities in their accumulation patterns in Parasol Mushrooms between the sampling sites, the CA was applied to the data set by using the Ward's method combined with 1Pearson $r$ method (Yetimoĝlu and Ercan 2008). The results of CA are shown in Figs. A.4 and A.5 (online resource). A cluster analysis dendrogram of the element concentration similarities for caps show two main clusters (online resource, Fig. A.4). The first cluster contains $\mathrm{K}, \mathrm{Mn}, \mathrm{Rb}$, $\mathrm{Mg}$, and $\mathrm{Zn}$. The second cluster contains $\mathrm{Al}, \mathrm{Fe}, \mathrm{Ba}, \mathrm{Sr}, \mathrm{Cd}$, $\mathrm{Hg}$, and $\mathrm{Cu}$. In the case of stipes, a dendrogram also indicates two main clusters (online resource, Figs. A.4). The first fraction separated elements such as $\mathrm{K}, \mathrm{Ba}, \mathrm{Sr}, \mathrm{Mn}$, $\mathrm{Al}, \mathrm{Fe}$, and $\mathrm{Cu}$ while the second fraction such as $\mathrm{Mg}, \mathrm{Rb}$, $\mathrm{Zn}, \mathrm{Cd}$, and $\mathrm{Hg}$. The dendrogram of the data set for caps of Parasol Mushrooms shows how sampling sites are clearly divided into two clusters with different characteristics regarding the measured concentrations of metals (online resource, Figs. A.5). In the first fraction, the strongest similarity occurred between the SZ-ML sites and TPKMW sites. In the second case, up to two subfractions could be recognized, which described the CZ-RA and OL-ST sites. A cluster analysis diagram of the data for stipes of Parasol Mushroom (online resource, Figs. A.5) shows that the sampling sites such as SZ-ML, CZ-OL-ST and TPKMW-RA are grouped separately.

\section{Conclusions}

A potential of Parasol Mushrooms to bioconcentrate in fruiting bodies certain metals contained in soil can be very high. The Parasol Mushroom is a species harvested in the wild, and its caps are of unique taste and can contain a spectrum of essential and hazardous mineral compounds accumulated to elevated concentrations, even if grown at the background (pristine) areas. The estimated intake rates of $\mathrm{Cd}, \mathrm{Hg}$, and $\mathrm{Pb}$ with the Parasol Mushroom's caps show a cause for concern associated with these metals resulting from the con- sumption of between 300- and 500-g caps daily, on a frequent basis in the mushrooming season.

Acknowledgments Technical support by Krzysztof Lipka and Ewa Łukaszewicz is acknowledged. This study in part has been supported by the Ministry of Science and Higher Education of Poland under grant no. DS-8025-4-0092-11.

Open Access This article is distributed under the terms of the Creative Commons Attribution Noncommercial License which permits any noncommercial use, distribution, and reproduction in any medium, provided the original author(s) and source are credited.

\section{References}

Alonso J, García MÁ, Pérez-López M, Melgar MJ (2003) The concentrations and bioconcentration factors of copper and zinc in edible mushrooms. Arch Environ Contam Toxicol 44:180-188

Baptista P, Ferreira S, Soares E, Coelho V, de Lourdes BM (2009) Tolerance and stress response of Macrolepiota procera to nickel. J Agric Food Chem 57:7145-7152

Borovička J, Řanda Z, Jelínek E (2005) Gold content of ectomycorrhizal and saprobic macrofungi from non-auriferous and unpolluted areas. Mycol Res 109:951-955

Borovička J, ̌̌anda Z, Jelínek E, Kotrba P, Dunn CE (2007) Hyperaccumulation of silver by Amanita strobiliformis and related species of the section Lepidella. Mycol Res 111:13391344

Borovička J, Kotrba P, Gryndler M, Mihaljevič M, Řanda Z, Rohovec J, Cajthaml T, Stijve T, Dunn CE (2009) Bioaccumulation of silver in ectomycorrhizal and saprobic macrofungi from pristine and polluted areas. Sci Total Environ 408:2733-2744

Borovička J, Dunn CE, Gryndler M, Mihaljevič M, Jelínek E, Rohovec J, Rohošková M, Řanda Z (2010) Bioaccumulation of gold in macrofungi and ectomycorrhizae from the vicinity of the Mokrsko gold deposit Czech Republic. Soil Biol Biochem 42:83-91

Brzostowski A, Bielawski L, Orlikowska A, Plichta S, Falandysz J (2009) Instrumental analysis of metals profile in Poison Pax (Paxillus involutus) collected at two sites in Bory Tucholskie. Chem Anal (Warsaw) 54:907-920

Brzostowski A, Falandysz J, Jarzyńska G, Zhang D (2011a) Bioconcentration potential of metallic elements by Poison Pax (Paxillus involutus) mushroom. J Environ Sci Health A 46:378393

Brzostowski A, Jarzyńska G, Kojta AK, Wydmańska D, Falandysz J (2011b) Variations in metal levels accumulated in Poison Pax (Paxillus involutus) mushroom collected at one site over four years. J Environ Sci Health A 46:581-588

Carvalho MI, Pimentel AC, Fernandes B (2005) Study of heavy metals in wild edible mushrooms under different pollution conditions by $\mathrm{X}$ ray fluorescence spectrometry. Anal Sci 21:747-750

Cenci RM, Cocchi L, Petrini O, Sena F, Siniscalco C, Vescovi L (2010) Elementi chimici nei funghi superiori I funghi di riferimento come strumento di lavoro per la bioindicazione e la biodiversità. JRC Sci Tech Rep EUR 24415 IT 2010 (in Italian)

Chang ST (1990) Composition of foods mushrooms as food. Food Lab News 21:7-8

Chudzyński K, Falandysz J (2008) Multivariate analysis of elements content of Larch Bolete (Suillus grevillei) mushroom. Chemosphere 78:1230-1239 
Chudzyński K, Bielawski L, Falandysz J (2009) Mercury bioconcentration potential of Larch Bolete Suillus grevillei mushroom. Bull Environ Contam Toxicol 83:275-279

Chudzyński K, Jarzyńska G, Stefańska A, Falandysz J (2011) Mercury content and bio-concentration potential of Slippery Jack Suillus luteus mushroom. Food Chem 125:986-990

Cocchi L, Vescovi L, Petrini LE, Petrini O (2006) Heavy metals in edible mushrooms in Italy. Food Chem 98:277-284

Diehl JF, Schlemmer U (1984) Bestimmung der Bioverfügharkeit von Cadmium in der Pilzen durh fütterungsversuche. Zeit für Ernährungswissensschaft 23:126-135 (in German)

EU (2008) Commission Regulation (EC) No 629/2008 of 2 July 2008 amending Regulation (EC) No 1881/2006 setting maximum levels for certain contaminants in foodstuffs. Office J European Union 372008L173/6-9

European Food Safety Authority (EFSA) (2009) Cadmium in food. EFSA J 980:1-139. http://wwwefsaeuropaeu/cs/BlobServer/ Scientific_Opinion/contam_op_ej980_cadmium_en_rev1pdf? ssbinary=true/. Cited 12 Dec 2009

Falandysz J (1990) Mercury content of squid Loligo opalescence. Food Chem 38:171-177

Falandysz J (2002) Mercury in mushrooms and soil of the Tarnobrzeska Plain southeastern Poland. J Environ Sci Health A 37:343-352

Falandysz J (2008) Selenium in edible mushrooms. J Environ Sci Health C 26:256-299

Falandysz J, Brzostowski A (2007) Mercury and its bioconcentration factors in Poison Pax (Paxillus involutus) from various sites in Poland. J Environ Sci Health A 42:1095-1100

Falandysz J, Chwir A (1997) The concentrations and bioconcentration factors of mercury in mushrooms from the Mierzeja Wiślana sand-bar Northern Poland. Sci Total Environ 203:221-228

Falandysz J, Danisiewicz D (1995) Bioconcentration factors (BCF) of silver in wild Agaricus campestris. Bull Environ Contam Toxicol $55: 122-129$

Falandysz J, Gucia M (2008) Bioconcentration factors of mercury by Parasol Mushroom (Macrolepiota procera). Environ Geochem Health 30:121-125

Falandysz J, Bona H, Danisiewicz D (1994a) Silver content of wildgrown mushrooms from northern Poland. Z Lebensm Unters Forsch 199:223-224

Falandysz J, Bona H, Danisiewicz D (1994b) Silver uptake by Agaricus bisporus from an artificially enriched substrate. Z Lebensm Unters Forsch 199:225-228

Falandysz J, Szymczyk K, Ichihashi H, Bielawski L, Gucia M, Frankowska A, Yamasaki S (2001) ICP/MS and ICP/AES elemental analysis (38 elements) of edible wild mushrooms growing in Poland. Food Addit Contam 18:503-513

Falandysz J, Bielawski L, Kannan K, Gucia M, Lipka K, Brzostowski A (2002a) Mercury in wild mushrooms and underlying soil substrate from the great lakes land in Poland. J Environ Monit 4:473-476

Falandysz J, Bielawski L, Kawano M, Brzostowski A, Chudzyński K (2002b) Mercury in mushrooms and soil from the Wieluńska Upland in south-central Poland. J Environ Sci Health A 37:1409-1420

Falandysz J, Gucia M, Skwarzec B, Frankowska A, Klawikowska K (2002c) Total mercury in mushrooms and underlying soil from the Borecka Forest Northeastern Poland. Arch Environ Contam Toxicol 42:145-154

Falandysz J, Lipka K, Gucia M, Kawano M, Strumnik K, Kannan K (2002d) Accumulation factors of mercury in mushrooms from Zaborski Lndscape Park Poland. Environ Int 28:421-427

Falandysz J, Brzostowski A, Kawano M, Kannan K, Puzyn T, Lipka K (2003a) Concentrations of mercury in wild growing higher fungi and underlying substrate near Lake Wdzydze Poland. Water Air Soil Pollut 148:127-137
Falandysz J, Kawano M, Świeczkowski A, Brzostowski A, Dadej M (2003b) Total mercury in wild-grown higher mushrooms and underlying soil from Wdzydze Landscape Park Northern Poland. Food Chem 81:21-26

Falandysz J, Lipka K, Kawano M, Brzostowski A, Dadej M, Jędrusiak A, Puzyn T (2003c) Mercury content and its bioconcentration factors in wild mushrooms at Łukta Northeastern Poland. J Agric Food Chem 51:2832-2836

Falandysz J, Jędrusiak A, Lipka K, Kurunthachalam K, Kawano M, Gucia M, Brzostowski A, Dadej M (2004) Mercury in wild mushrooms and underlying soil substrate from Koszalin Northcentral Poland. Chemosphere 54:461-466

Falandysz J, Gucia M, Mazur A (2007a) Content and bioconcentration factors of mercury by Parasol Mushroom Macrolepiota procera. J Environ Sci Health B 42:735-740

Falandysz J, Kunito T, Kubota R, Lipka K, Mazur A, Falandysz JJ, Tanabe S (2007b) Selected elements in Fly Agaric Amanita muscaria. J Environ Sci Health A 42:1615-1623

Falandysz J, Kunito T, Kubota R, Bielawski L, Frankowska A, Falandysz JJ, Tanabe S (2008a) Multivariate characterization of elements accumulated in King Bolete Boletus edulis mushroom at lowland and high mountain regions. J Environ Sci Health A 43:1692-1699

Falandysz J, Kunito T, Kubota R, Gucia M, Mazur A, Falandysz JJ, Tanabe S (2008b) Some mineral constituents of Parasol Mushroom Macrolepiota procera. J Environ Sci Health B 43:187-192

Falandysz J, Frankowska A, Jarzyńska G, Dryżałowska A, Kojta AK, Zhang D (2011) Survey on composition and bioconcentration potential of 12 metallic elements in King Bolete (Boletus edulis) mushroom that emerged at 11 spatially distant sites. J Environ Sci Health B 46:231-246

Frankowska A, Ziółkowska J, Bielawski L, Falandysz J (2010) Profile and bioconcentration of minerals by King Bolete (Boletes edulis) from the Płocka Dale in Poland. Food Addit Contam B 3:1-6

Gadd GM (2007) Geomycology: biogeochemical transformations of rocks minerals metals and radionuclides by fungi bioweathering and bioremediation. Mycol Res 111:3-49

García MÁ, Alonso J, Melgar MJ (2009) Lead in edible mushrooms. Levels and bioconcentration factors. J Haz Mat 167:777-783

Gumińska B, Wojewoda W (1988) Grzyby i ich oznaczanie. PWRiL, Warszawa

Jarzyńska G, Falandysz J (2011a) The determination of mercury in mushrooms by CV-AAS and ICP-AES techniques. J Environ Sci Health A 46:569-573

Jarzyńska G, Falandysz J (2011b) Selenium and 17 other largely essential and toxic metals in muscle and organ meats of Red Deer (Cervus elaphus)-Consequences to human health. Environ Intern 37:882-888

JECFA (1978) Evaluation of certain food additives and contaminants Twenty-second report of the Joint FAO/WHO Expert Committee on Food Additives WHO Technical Report Series 631

Lind Y, Glynn AW, Engmam J, Jorhem L (1995) Bioavailability of cadmium from crab hepatopancreas and mushroom in relation to inorganic cadmium: a 9-week feeding study in mice. Food Chem Toxicol 33:667-673

Malinowska E, Szefer P, Falandysz J (2004) Metals bioaccumulation by bay bolete Xerocomus badius from selected sites in Poland. Food Chem 84:405-416

Melgar MJ, Alonso J, Pérez-López M, García MÁ (1998) Influence of some factors in toxicity and accumulation of cadmium from edible wild macrofungi in NW Spain. J Environ Sci Health B 33:439-455

Melgar MJ, Alonso J, García MÁ (2009) Mercury in edible mushrooms and soil. Bioconcentration factors and toxicological risk. Sci Total Environ 407:328-5334 
Mitra AK, Purkayastha RP, Chantterjee NB, Bhattacharyya R (1995) Uptake and tissue distribution of cadmium in albino rat after oral exposure to cadmium-contaminated edible mushroom and its effect on blood. Curr Sci 68:1050-1053

Schellmann B, Hilz MJ, Optiz O (1980) Cadmium-und Kupferausscheidung Nach Aufnahme Von Champignon-Mahizeiten. Zeitschr Lebensm Unters Forsch 171:189-192 (in German)

Seeger R, Schiefelbein F, Senffert R, Zant W (1986) Absorption of cadmum ingested with mushrooms. Naunyn-Schmiedeberg's Arch Pharmacol 332:110

Singer R (1946) New and interesting species of Basidiomycetes. Pap Mich Aca Sci Arts Lett 32:141

Stijve T, Besson R (1976) Mercury cadmium lead and selenium content of mushroom species belonging to the genus Agaricus. Chemosphere 7:151-158

Stijve T, Roschnik R (1974) Mercury and methyl mercury content of different species of fungi. Trav Chim Aliment Hyg 65:209-220

Stijve T, Vellinga EC, Herrmann A (1990) Arsenic accumulation in some higher fungi. Personia 14:161-166

Stijve T, Noorloos T, Byrne AR, Slejkovec Z, Goessler H (1998) High selenium levels in edible Albatrellus mushrooms. Deutsch Lebensm-Runds 94:275-279
US EPA (2005) Toxicological review of zinc and compounds. In support of summary information on the integrated risk information system. US Environmental Protection Agency, Washington DC

Vetter J, Siller I (1997) Ásványi anyagok mennyiségének alakulása a gomba termőtestben (Macrolepiota procera). Mikolódiai Közlemények 36:33-39 (in Hungarian)

World Health Organization (WHO) (1989) Toxicological evaluation of certain food additives and contaminants 33rd Report of the Joint FAO/WHO Expert Committee on Food Additives Food Additives Series No 24 Geneva (Switzerland)

World Health Organization (WHO) (1993) Evaluation of certain food additives and contaminants 41 st Report of the Joint FAO/WHO Expert Committee on Food Additives Technical Report Series No 837 Geneva (Switzerland)

Yetimoĝlu EK, Ercan Ö (2008) Multivariate analysis of metal contamination in street dusts of Istanbul D-100 highway. J Braz Chem Soc 19:1399-1404

Zhang D, Frankowska A, Jarzyńska G, Kojta AK, Drewnowska M, Wydmańska D, Bielawski L, Wang J, Falandysz J (2010) Metals of King Bolete (Boletus edulis) Bull: Fr collected at the same site over two years. Afr J Agric Res 5:3050-3055 